\title{
LAMP2 wt Allele
}

National Cancer Institute

\section{Source}

National Cancer Institute. LAMP2 wt Allele. NCI Thesaurus. Code C116023.

Human LAMP2 wild-type allele is located in the vicinity of Xq24 and is approximately $43 \mathrm{~kb}$ in length. This allele, which encodes lysosome-associated membrane glycoprotein 2 , is involved in the maintenance of the lysosome. Mutation of the gene is associated with Danon disease. 